\title{
OPEN
}

\section{Author Correction: CD44 variant inhibits insulin secretion in pancreatic $\beta$ cells by attenuating LAT1-mediated amino acid uptake}

\author{
Nana Kobayashi, Shogo Okazaki, Oltea Sampetrean, Junichiro Irie $\mathbb{B}^{\circ}$, Hiroshi Itoh \& \\ Hideyuki Saya $\mathbb{B}$
}

Correction to: Scientific Reports https://doi.org/10.1038/s41598-018-20973-2, published online 12 February 2018

This Article contains errors. The information in this Article is incomplete. The clone for the CD44v antibody is RM1. It is now available from Cosmo Bio USA.

\begin{abstract}
(c) (i) Open Access This article is licensed under a Creative Commons Attribution 4.0 International License, which permits use, sharing, adaptation, distribution and reproduction in any medium or format, as long as you give appropriate credit to the original author(s) and the source, provide a link to the Creative Commons license, and indicate if changes were made. The images or other third party material in this article are included in the article's Creative Commons license, unless indicated otherwise in a credit line to the material. If material is not included in the article's Creative Commons license and your intended use is not permitted by statutory regulation or exceeds the permitted use, you will need to obtain permission directly from the copyright holder. To view a copy of this license, visit http://creativecommons.org/licenses/by/4.0/.
\end{abstract}

(C) The Author(s) 2020 